\title{
Evaluation of the Role of Serum Level of YKL-40 Protein as a Diagnostic Test in Asthmatic Children Patients in El-Minia Governorate
}

\author{
${ }^{1}$ Khaled Hussein M. El Dessouki, ${ }^{2}$ Mohamed Ahmed Bahaa el-deen, ${ }^{3}$ Ahmed Hussein Kasem \\ ${ }^{1}$ Department of Public health and preventive medicine, ${ }^{2}$ Department of Pediatrics, \\ ${ }^{3}$ Departement of chest diseases Faculty of Medicine, Minia University, Egypt.
}

Received: April, $2018 \quad$ Accepted: June, 2018

\begin{abstract}
Background: The global prevalence of asthma ranges from from $1 \%$ to $18 \%$ of the population with significant differences among countries (about 300 million affected persons globally). YKL-40 (chitinase 3-like protein 1) is a glycopeptide produced and secreted from different cells including epithelial and smooth muscle cells of airways. It has been involved in inflammation and tissue remodeling, and increased expression of YKL-40 in diseases with Thelper-2 inflammation e.g. asthma. Objective: To evaluate the serum levels of YKL-40 in a group of Egyptian asthmatic children (both stable and acute) and compare them to a matched healthy control group. Method: This case-control study was conducted at Minia university hospitals, it was held from January 2017 to May 2017, sixty patients were included as cases which were divided into 2 subgroups: 30 acute asthmatics and 30 stable asthmatics in addition to 30 healthy age-matched children were included as controls. They were recruited from the follow-up clinics of the hospital after consent from their caregivers. Detailed history and complete physical examination were done to all children. A complete blood count was performed and estimation of serum YKL-40 level was performed using a commercial enzymelinked immune sorbent assay (ELISA) kit. Results: YKL-40 Serum levels are significantly higher in children with bronchial asthma compared to healthy controls. Acute asthmatic children serum levels of YKL-40 are significantly higher in comparison to stable asthmatics. Conclusion: The study concludes that YKL-40 might have a role in pediatric asthma pathogenesis; however, further research on a larger scale is warranted.
\end{abstract}

Keywords: Asthma; children; YKL-40; Biomarker; Minia

Corresponding author: Khaled Hussein M. El Dessouki Email: kddsok@gmail

\section{Introduction}

Asthma is a multifactorial disease with reversible respiratory airway obstruction due to a chronic inflammatory reaction in the bronchi. Bronchial asthma symptoms like cough, rhonchi, wheezing, or dyspnea are correlated with the limitation of expiratory airflow, and bronchial increased responsiveness. ${ }^{1}$ Prevalence of pediatric asthma in Egyptian school children around 9\%. ${ }^{2}$ In Egypt, $23.2 \%$ of wheezy infants were proven to be real asthmatics. In 2003, asthma prevalence among school children aged 5-15years was found to be $8.2 \%$, half of which are graded as moderate to severe asthmatics. ${ }^{3}$ In 2008 , there was an increase in the prevalence of asthma among school-age children with a mean of $15.1 \%$. There was an increase in 
asthma prevalence in urban areas compared to rural areas, exposure to environmental tobacco smoke, and air pollution were important contributing factors of bronchial asthma. ${ }^{4}$ A study conducted in Egypt revealed that the prevalence rate of childhood asthma in Nile delta region of Egypt was 7.7\% of (8\% in urban and $7 \%$ in rural areas). ${ }^{5}$

YKL-40 is a chitinase-like protein; it is a $40 \mathrm{kDA}$ (kilodalton) heparin binding glycoprotein. ${ }^{6}$ YKL-40 binds chitin which is a polysaccharide composed of $\mathrm{N}$ acetylglucosamine, it is produced at sites of inflammation in many cells and is secreted from macrophages and smooth muscle cells of blood vessels. ${ }^{7}$ YKL-40 is stored in specific granules of neutrophil cells and released from neutrophils, chondrocytes, macrophages, vascular smooth muscle and cancer cells. ${ }^{8}$ It is suggested that YKL-40 has a role in inflammation and tissue remodeling in human diseases, such as joint injury, liver fibrosis, type 2 diabetes. ${ }^{6,7,9}$ It is established that YKL-40 was increased in the circulation and lung of severe asthmatic patients so, that YKL-40 could either be a marker or cause for bronchial asthma. ${ }^{10}$ Few studies have demonstrated increased levels of YKL-40 in asthmatics compared to controls, ${ }^{11}$ studied the applicability of YKL-40 as a good biomarker of asthma, its control, and severity. The YKL-40 is significantly higher in asthmatic patients than the control group and its level has a positive correlation with the eosinophils number. Then again, they found no relation between serum level of YKL- 40 and severity of bronchial asthma or control. Similar studies ${ }^{12,13}$ were conducted and yielded comparable results.

The aim of this study is to evaluate the serum levels of YKL-40 in a group of Egyptian asthmatic children (both stable and acute) and compare them to a matched healthy control group, with emphasis on the relation between YKl-40 and clinical and laboratory parameters of the patients.

\section{Method}

Study design, time and place: This study is a Hospital based case-control analytical study and was conducted at Minia university hospital for pediatrics, gynecology, and obstetrics in the period from January 2017 to May 2017.

Study population and sample size: Sixty patients were included. They were divided into two subgroups: 1. Sub Group I: included 30stable asthmatic children diagnosed according to Global Initiative for Asthma(GINA) guidelines and were following-up in the chest clinic of the hospital. 2. Sub Group II: Included 30 children with acute asthma attacks (mild, moderate, or severe according to GINA guidelines); they were recruited from the emergency department of the hospital.

Thirty healthy children were included in this study as controls, they were recruited from the follow-up clinics of the hospital after consent from their caregivers, there were age-and sex-matching of the control group to the cases group. Complete history taking, complete physical examination, 
Table (1): Clinical and laboratory data of all cases $(n=60)$

\begin{tabular}{lcccc}
\hline \multicolumn{1}{c}{ Variable } & Min. & Max. & Mean & $\begin{array}{c}\text { Standard } \\
\text { deviation }\end{array}$ \\
\hline $\begin{array}{l}\text { Sex: n (\%) } \\
\text { Males } \\
\text { Females }\end{array}$ & & & & $24(40 \%)$ \\
\hline Age (years) & 2.5 & 6 & 4.8 & 1.1 \\
\hline Heart rate(per minute) & 80 & 120 & 96.0 & 9.9 \\
\hline Respiratory rate (per minute) & 28.0 & 50 & 39.2 & 6.2 \\
\hline Temperature (celsius) & 36.0 & 37.6 & 36.9 & 0.3 \\
\hline Hemoglobin (g/d) & 8.9 & 16.4 & 12.7 & 2.0 \\
\hline Total leucocytic count (103/cmm) & 4.6 & 10.4 & 7.3 & 3.7 \\
\hline Eosinophil percentage & 0 & 4 & 1.2 & 0.9 \\
\hline Absolute eosinohilic count $(\mathbf{c e l l} / \mathbf{c m m})$ & 0 & 412.0 & 73.5 & 51.8 \\
\hline Serum ykl-40 (ng/ml) & 4 & 49.0 & 25.2 & 11.7 \\
\hline
\end{tabular}

and Laboratory investigations were done to all children

Table (2): Clinical and laboratory data of acute asthmatics $(n=30)$

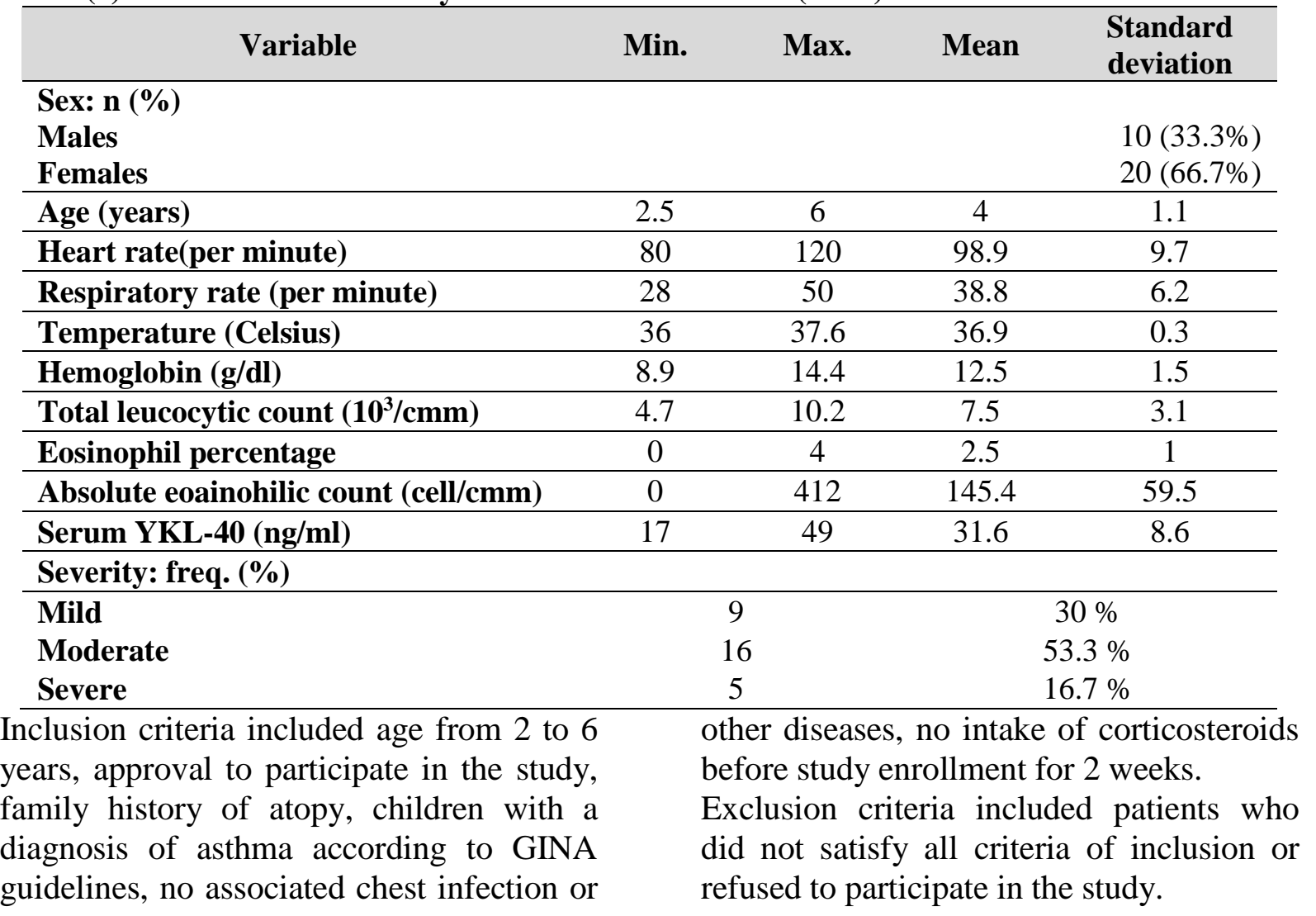


Table (3): Clinical and laboratory data of stable asthmatics $(n=30)$

\begin{tabular}{lcccc}
\hline \multicolumn{1}{c}{ Variable } & Min. & Max. & Mean & $\begin{array}{c}\text { Standard } \\
\text { deviation }\end{array}$ \\
\hline $\begin{array}{l}\text { Sex: n (\%) } \\
\text { Males }\end{array}$ & & & & $14(46.7 \%)$ \\
Females & & & & $16(53.3 \%)$ \\
\hline Age (years) & 2 & 6 & 4.8 & 1.2 \\
\hline Heart rate(per minute) & 80 & 110 & 93.1 & 9.4 \\
\hline Respiratory rate (per minute) & 28 & 35 & 25.5 & 4.4 \\
\hline Temperature (Celsius) & 36 & 37.6 & 37 & 0.3 \\
\hline Hemoglobin (g/dl) & 9.3 & 16.4 & 12.9 & 2.3 \\
\hline Total leucocytic count (10/(cmm) & 4.6 & 10.4 & 8.5 & 4 \\
\hline Eosinophil percentage & 0 & 2 & 1.1 & 0.5 \\
\hline Absolute eoainohilic count (cell/cmm) & 0 & 168 & 94.6 & 42 \\
\hline Serum YKL-40 (ng/ml) & 4 & 39 & 18.8 & 11 \\
\hline
\end{tabular}

Total volume of blood withdrawn from be used for CBC analysis and the other 2 each case is $4 \mathrm{ml}$, two milliliters were $\mathrm{ml}$ were added to plain red cap tube to be added to vacutainer containing EDTA to used for serum YKL-40 assay

Table (4): Comparison between acute, stable and controls:

\begin{tabular}{|c|c|c|c|c|c|c|c|}
\hline \multirow[b]{2}{*}{ Variable } & \multirow{2}{*}{$\begin{array}{c}\begin{array}{c}\text { Acute } \\
\mathbf{N}=30\end{array} \\
\text { Mean } \pm \mathrm{SD}\end{array}$} & \multirow{2}{*}{$\begin{array}{c}\begin{array}{c}\text { Stable } \\
\mathrm{N}=30\end{array} \\
\text { Mean } \pm \mathrm{SD}\end{array}$} & \multirow{2}{*}{$\begin{array}{c}\begin{array}{c}\text { Controls } \\
\mathrm{N}=30\end{array} \\
\text { Mean } \pm \text { SD }\end{array}$} & \multicolumn{4}{|c|}{ P-value } \\
\hline & & & & General & $\begin{array}{c}\text { Acute } \\
\& \\
\text { stable }\end{array}$ & $\begin{array}{c}\text { Acute } \\
\& \\
\text { controls } \\
\end{array}$ & $\begin{array}{c}\text { Stable } \\
\& \\
\text { controls } \\
\end{array}$ \\
\hline Age & $4.8 \pm 1.1$ & $4.7 \pm 1.1$ & $4.9 \pm 1.9$ & 0.895 & 0.929 & 0.723 & 0.657 \\
\hline $\begin{array}{l}\text { Male Sex: } N \\
(\%)\end{array}$ & $10(33.3)$ & $14(46.7)$ & $21(70)$ & 0.160 & 0.060 & 0.059 & 0.092 \\
\hline Heart rate & $98.9 \pm 9.6$ & $93.1 \pm 9.4$ & $94.4 \pm 12.4$ & 0.093 & 0.058 & 0.106 & 0.636 \\
\hline $\begin{array}{l}\text { Respiratory } \\
\text { rate }\end{array}$ & $38.8 \pm 6.1$ & $25.5 \pm 4.4$ & $24.5 \pm 6.03$ & $<0.001^{*}$ & $0.001 *$ & $<0.001 *$ & 0.644 \\
\hline Temperature & $36.9 \pm 0.3$ & $36.9 \pm 0.3$ & $36.8 \pm 0.4$ & 0.493 & 0.716 & 0.424 & 0.246 \\
\hline Hemoglobin & $12.4 \pm 1.4$ & $12.9 \pm 2.3$ & $12.1 \pm 0.5$ & 0.165 & 0.283 & 0.407 & 0.059 \\
\hline TLC & $7.5 \pm 3.1$ & $8.5 \pm 3.9$ & $8.3 \pm 2.4$ & 0.231 & 0.062 & $<0.146$ & 0.350 \\
\hline $\begin{array}{l}\text { Eosinophil } \\
\text { percentage }\end{array}$ & $2.5 \pm 0.9$ & $1.1 \pm 0.5$ & $0.56 \pm 0.5$ & $<0.001^{*}$ & $<0.001 *$ & $0.012^{*}$ & $0.030 *$ \\
\hline $\begin{array}{l}\text { Absolute } \\
\text { eosinophilic } \\
\text { count }\end{array}$ & $145.4 \pm 59.4$ & $94.6 \pm 41.9$ & $49 \pm 41.8$ & $0.001 *$ & $0.021 *$ & $0.014 *$ & $0.034 *$ \\
\hline $\begin{array}{l}\text { Serum YKL } \\
\text { ng/ml }\end{array}$ & $31.5 \pm 8.5$ & $18.8 \pm 10.9$ & $13.5 \pm 8.1$ & $<0.001^{*}$ & $<0.001 *$ & $<0.001 *$ & $0.004 *$ \\
\hline
\end{tabular}

CBC was done using automated cell counter, Mindray BC - 3600 auto hematology analyzers, China.

YKL-40 assay was performed using a commercial ELISA (enzyme-linked immune-sorbent assay) kit WKEA MED SUPPLIES CROP, Changchun 130012 China.
Steps of KL-40 assay:

1- Dilute and add sample to Standard: By using 10 Standard wells were set on the ELISA plates coated (add Sample 50 $\mu$ to each well after Diluting, (density: 150 $\mathrm{ng} / \mathrm{ml}, 100 \mathrm{ng} / \mathrm{ml}, 50 \mathrm{ng} / \mathrm{ml}, 25 \mathrm{ng} / \mathrm{ml}, 12.5$ $\mathrm{ng} / \mathrm{ml})$. 
2- Adding sample: Set separately the Blank wells and the sample tested well. Sample dilution $40 \mu \mathrm{l}$ added to the testing sample well, then testing sample $10 \mu \mathrm{l}$ was added, sample added to wells, and gently mixed.

3-Incubation: close the plate with Closure plate membrane, and incubated for $30 \mathrm{~min}$ at $37^{\circ} \mathrm{C}$.

4-Configuration liquid: 30-fold wash solution diluted with distilled water and reserved.

5-Washing: Uncover the Closure plate membrane, discard the liquid, dry it by swing, washing buffer added to every well, for the $30 \mathrm{~s}$ then drained, repeated 5 times, dried by pat.

6-Adding enzyme: HRP-Conjugate reagent $50 \mu l$ added to each well, except blank well.

7-Incubation: Operation with 3.

8-Washing: Operation with 5.

9-Color: Chromogen Solution A 50ul and Chromogen Solution B was Added to each well, the light preservation evaded for 15 $\min$ at $37^{\circ} \mathrm{C}$

10- Stop the reaction: Stop Solution $50 \mu 1$ added to each well, the blue color change to yellow.

11-Assay: blank well taken as zero, absorbance red at $450 \mathrm{~nm}$ after adding Stop Solution and within $15 \mathrm{~min}$.

Collection, revision, verification of data were done, then coded, and entered PC by using SPSS statistical package version 20.

Number and percentage were used for qualitative data. Mean and standard deviation was used for quantitative data. To differentiate between parametric data and non-parametric data we used KolmogorovSmirnov test.

Normally distributed variables (parametric) between more than two study groups were analyzed using: -Chi-square (x2) for analysis of qualitative data. Fischer's exact test also used. ANOVA test for comparison of quantitative data. Bivariate correlation analysis for association analysis. Independent sample t-test for comparison of quantitative data between two groups.

For all tests probability (p) was considered non-significant if $\geq 0.05$, significant if < 0.05 , highly significant if $<0.01$ and very

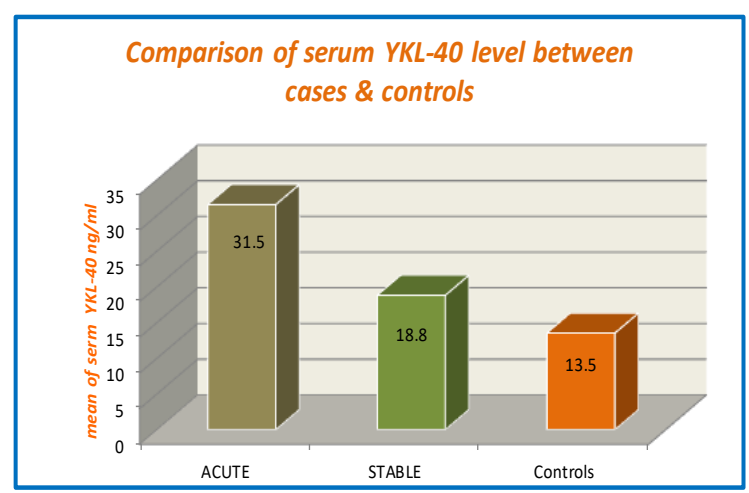

highly significant if $<0.001$

Figure (1): Comparison of serum YKL-40 level between cases \& controls

Grade of correlation is weak if from 0.00 to 0.24 , fair if from 0.25 to 0.49 , moderate if from 0.50 to 0.74 and strong if equal to or more than 0.75 .

\section{Ethical consideration}

Data were collected after a verbal consent of the parents of the children after they were informed about the objective, procedures, benefits, and possible risks of the study. The respondents' identification was only through numerical codes for confidentiality.

\section{Results}

Sixty asthmatic children were enrolled in this study (30 patients of acute asthma and 30 patients of stable asthma), they were age- and sex-matched to control group of 30 healthy children. Demographic, clinical and laboratory data of all cases presented in Table (1). Clinical and laboratory data of acute asthmatics presented in Table (2). Clinical and laboratory data of stable asthmatics presented in Table (3). 


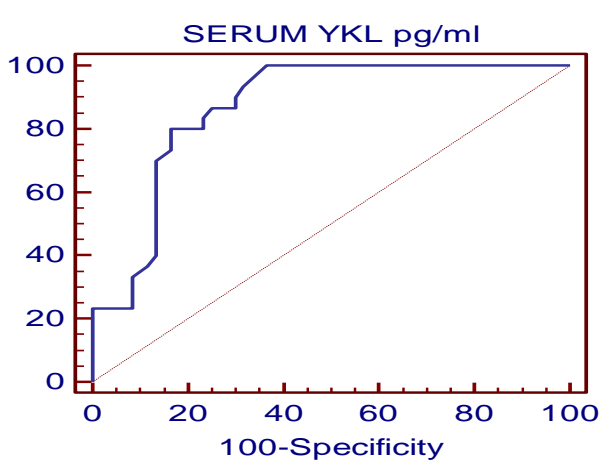

Figure (2): Diagnostic Value of YKL-40 in Asthma

There was a significant difference between 3 groups in eosinophilic percentage, eosinophilic count and serum YKL40, where mean eosinophilic percentage is $2.5 \pm 0.9 \%$ in acute asthma, $1.1 \pm 0.5 \%$ in stable asthmatic, $0.56 \pm 0.5 \%$ in controls, the mean serum eosinophils in acute asthma is $145.4 \pm 59.4 \mathrm{c} / \mathrm{cmm}, \quad 94,6 \pm$ $41.9 \mathrm{c} / \mathrm{cmm}$ in stable asthma, $49 \pm 41.8$ $\mathrm{c} / \mathrm{cmm}$. The mean serum YKL40 is $31.5 \pm$ $8.5 \mathrm{ng} / \mathrm{ml}$ in acute asthma, 18.8 \pm 10.9 $\mathrm{ng} / \mathrm{ml}$ in stable asthmatics and $13.5 \pm 8.1 \mathrm{ng} /$ $\mathrm{ml}$ in controls. There is also a significant difference between acute\& stable, acute and controls in respiratory rate where mean $\mathrm{RR}$ is $38.8 \pm 6.1$ breath/minute in acute group, $25.5 \pm 4.4$ breath/ minute in stable asthma, 24.5 \pm 6.03 in controls. These results are shown in the table (4).

Table (5): ROC curve analysis for the sensitivity of serum YKL-40 in an asthmatic patient

\begin{tabular}{lc}
\hline \multicolumn{1}{c}{ Value } & Result \\
\hline $\begin{array}{l}\text { Area under the ROC curve } \\
\text { (AUC) }\end{array}$ & 0.869 \\
\hline Cutoff point & $>25 \mathrm{ng} / \mathrm{ml}$ \\
\hline Sensitivity & $80 \%$ \\
\hline Specificity & $83.3 \%$ \\
\hline Standard Error & 0.0367 \\
\hline 95\% Confidence Interval & $0.782-0.931$ \\
\hline
\end{tabular}

\begin{tabular}{ll}
\hline Significance level (P-value) & $<0.001$ \\
\hline Positive predictive value & $82.7 \%$ \\
\hline Negative predictive value & $80.6 \%$ \\
\hline
\end{tabular}

There was a difference between acute and stable asthmatics in YKL40 level, the serum YKL40 in acute asthmatics is 31.5 $\mathrm{ng} / \mathrm{ml}$ while $18.9 \mathrm{ng} / \mathrm{ml}$ in stable asthmatics as presented in figure (1). This figure shows the highly significant difference in YKL 40 level between acute and stable asthmatics, acute and controls and the significant difference between stable and controls in its level, where its serum level is $31.5 \mathrm{ng} / \mathrm{ml}$ in acute asthmatics, 18.8 $\mathrm{ng} / \mathrm{ml}$ in stable asthmatics, $13.5 \mathrm{ng} / \mathrm{ml}$ in controls. This study shows correlation between YKL-40 level and other variables with very highly significant correlation with eosinophilic percentage $(r=0.943)$, absolute eosinophilic count $(r=0.876)$ and severity of asthma( $\mathrm{r}=0.748)$ with $\mathrm{p}$-value < 0.001

There was a very highly significant moderate correlation between YKL 40 and severity of asthma ( $\mathrm{r}=0.748$, p-value < $0.001)$ where the median in mild group is $26 \mathrm{ng} / \mathrm{ml}$ with IQR 18.5-29.5, while in moderate asthma the median is $32 \mathrm{ng} / \mathrm{ml}$ with IQR 29-36, and in severe attack the median is $43 \mathrm{ng} / \mathrm{ml}$ with interquartile range 41-47.

ROC curve analysis shows that sensitivity of serum YKL-40 in an asthmatic patient is $80 \%$, specificity is $83.3 \%$, cutoff point > $25 \mathrm{ng} / \mathrm{ml}$ with $95 \%$ confidence interval from 0.782 to 0.931 with $\mathrm{p}$-value $<0.001$ this is shown in the table (5) and figure (2).

\section{Discussion}

Bronchial asthma is the most common chronic disease in children and it extremely affects a minority of low socioeconomic level children and those in urban areas. ${ }^{14}$ The incidence of childhood 
asthma is increasing, the estimated incidence among at-risk children was 12.5/1000. ${ }^{15}$ In Egypt, $23.2 \%$ of wheezy infants were proven to be real asthmatics. In 2003, asthma prevalence among school children aged 5-15 years was found to be $8.2 \%$, half of them are classified as moderate to severe asthmatics ${ }^{3}$, asthma results in a loss of lung function, if not early diagnosed and treated leading to impaired quality of life and the risk to die from uncontrolled attacks asthma. ${ }^{16}$

Recently, chitinase-like proteins, YKL-40 (chitinase-3-like-1), also synonymed as (human cartilage glycoprotein-39), discovered to be potential biomarkers of asthma and it is synthesized in neutrophil precursors and released from chondrocytes, macrophages, neutrophils, smooth muscle of blood vessels and cancer cells. ${ }^{8}$ YKL-40 is a respectable biomarker of lung inflammatory diseases and this is due to the correlation of serum level of YKL-40 with the respiratory system lining cells. ${ }^{17}$ In patients with bronchial asthma, YKL-40 is expressed by macrophages in specimens of bronchial biopsy and broncho-alveolar lavage. ${ }^{18}$

Serum level of YKL-40 has been revealed to be increased in the asthmatic patients and to correlate with markers of disease severity. ${ }^{19}$ It has been stated that YKL-40 stimulates interleukin-13 pathway and causes more inflammation in asthmatic patients. ${ }^{20}$

The results of the present study revealed that there were no significant differences between cases and control groups regarding sex distribution but in the asthmatic group, females were higher than in the control group (60.0\% vs. $30.0 \%)$. Also, there was no statistically significant difference between groups regarding children age. These results agreed with the results of a study carried out in Egypt by
Mohamad et al., ${ }^{21}$ who studied serum YKL-40 levels in two groups of asthmatic children (group (I) stable group and group (II) acute attack group) compared to healthy control children, they found that there was no significant difference regarding age and sex distribution between asthmatic and controls but they noticed that asthmatic patients showed predominance in males (68.33\%) more than females (31.67\%). Also, these findings are supported by other studies ${ }^{22}$ who stated that there was no significant sex difference in pediatric asthma.

Regarding respiratory rate, the results showed that it was significantly higher in acute asthmatic children as compared to control (38.8 vs. 24.5 ), but, there was no significant difference in respiratory rate between stable asthma and control asthma groups. These results agreed with. ${ }^{23}$

The results showed that eosinophils percentage was significantly higher in asthmatic children than control (1.2 vs. $0.56 \%$ ), this result matched with others' results $^{21}$ who found that eosinophils percentage was 204.37 in control group and was 535.2 in stable asthma cases and was 616.67 in acute asthma children with a significant difference among groups. Also, similar results were found by other study ${ }^{24}$, these results may be explained by that migration of neutrophils to IL-8 which later cause accumulation of eosinophils in the airways of the asthmatic patients as it was reported by other studies ${ }^{23,25}$ that reported that the severity of asthma is mainly responsible for the number of eosinophils in peripheral blood and in bronchial lavage from asthmatic patients.

Alternatively, Jayaram et al. ${ }^{26}$ found that severe and persistent asthmatic patients may have not eosinophilic inflammation and exacerbation of asthma may occur without any increase in eosinophilic number. The present results showed that 
serum YKL-40 levels were significantly different among the three groups, acute asthma group had the higher concentration $(31.5 \mathrm{ng} / \mathrm{mL})$ follow it with a very highly significant difference the stable asthma group (18.8 $\mathrm{ng} / \mathrm{mL})$ and the lower concentration was found in control group $(13.5 \pm 8.1 \mathrm{ng} / \mathrm{mL})$ with a significant differences from the two asthmatic groups(acute \& stable). Also, YKL-40 protein was correlated positively with the severity of the disease. These results agreed typically with the results of mohamad et al study ${ }^{21}$ who establish_that the serum YKL-40 level was higher in the acute asthma patient group than patients in stable asthma group and the control group, also, they noticed that YKL-40 protein was correlated positively with the severity of asthma and these results are in agreement with other study ${ }^{27}$ who assessed the role of serum YKL-40 level in evaluating asthma severity in Egyptian children. They found that the serum levels of YKL-40 were significantly elevated in severely and moderate asthmatic children (151ng/ml$72 \mathrm{ng} / \mathrm{ml} ; \mathrm{p}<.05)$ compared to control $(35.7 \mathrm{ng} / \mathrm{ml})$. Similarly, Tang et $\mathrm{al}^{13}$ found that serum YKL-40 levels were increased significantly in bronchial asthma patients compared with controls and when the asthmatic patients were stratified. Serum YKL-40 levels in the exacerbation group were higher than those in the stable and control groups.

Accordingly, Kuepper et al ${ }^{10}$ tested YKL40 serum levels in 13 allergic asthma patients 24 before and $24 \mathrm{~h}$. after a segmental allergen test, they found that YKL-40 concentrations were significantly elevated in the serum before the test $(\mathrm{P}$ $=0.01$ ) and even more elevated $24 \mathrm{~h}$. after the test $(\mathrm{P}=0.003)$. Chupp et $\mathrm{al}^{18}$ assessed serum YKL-40 levels in three cohorts of patients with asthma and they found that YKL-40 was higher in patients with asthma in comparison with healthy persons. Also, Duru et $\mathrm{al}^{12}$ found a significant $(\mathrm{P}<0.0001)$ decrease in serum YKL-40 levels of well-controlled asthma patients than the acute exacerbation group. Furthermore, Konradsen et al. ${ }^{24}$ reported that serum levels of YKL-40 were higher significantly in therapy-resistant asthmatic children than in control children $(\mathrm{P}=$ 0.03). Additionally, Specjalski et al. ${ }^{11}$ found that YKL-40 levels in asthmatic patients were higher significantly in the subgroup with exacerbations and unfair control of asthmatic symptoms compared to stable asthmatics $(\mathrm{P}<0.001)$.

As matched with our findings, Ober et al. ${ }^{28}$ found that YKL-40 serum levels were 15\% higher in those with bronchial asthma than in controls. Similar to our results follow-up data was indicating significant higher serum levels of YKL-40 in asthmatic patients after they were tested with various allergens by kuepper et al. ${ }^{10}$ Also, Ober and Chupp $^{29}$ performed an analytical cross-sectional study of samples from an established group of asthmatic patients and controls and showed that YKL-40 levels were significantly higher in the serum of asthmatic subjects compared with nonasthmatic subjects. In addition, Leonardi et al. $^{30}$ evaluated serum levels of YKL40 in children with intermittent or persistent asthma, they found that circulating YKL40 levels are significantly higher in asthmatic patients than healthy subjects $(36 \pm 18.6$ vs. $14: 41 \pm 2.88, \mathrm{p}<0.001)$, also, there were significantly higher values of YKL-40 in both groups of children patients with intermittent asthmatic attacks ( $\mathrm{p}<0.001)$ and persistent asthma ( $<$ < $0.001)$ than healthy controls.

Additionally, Specjalski et al. ${ }^{11}$ investigated the diagnostic role of YKL-40 as a promising biomarker of asthma; they found that serum YKL-40 level was with a significant difference between asthmatic 
patients and healthy control group. In asthmatics, serum YKL-40 level was significantly higher in the subgroup with poor control of symptoms and exacerbations compared to stable asthmatics as well as in atopic compared to non-atopic asthmatics.

Gavala et al. ${ }^{31}$ found correlations between serum level of YKL-40 and profibrotic factors which also support the association of chitinases in remodeling the airways, YKL- 40 binds to collagen I and can adjust the formation of collagen fibrils ${ }^{32}$ and has been shown to increase the proliferation and migration of bronchial smooth muscle cells. ${ }^{33}$ Furthermore, some researchers explain the significant rise of YKL-40 in severe asthmatics by the pathophysiological role of YKL-40 in asthma as it is Th2- cytokine IL-13 dependent ${ }^{10}$, it was reported that YKL-40 have been linked to airway inflammation. ${ }^{34}$ Zhu et al. ${ }^{20}$ described that YKL-40 stimulates interleukin-13 pathway and increases inflammation in asthmatic patients, this is because of the correlation of serum YKL-40 level with that level in respiratory system lining cells. ${ }^{17,35}$ In asthmatic patients, YKL-40 is expressed by macrophages in bronchial biopsy specimens and also their broncho-alveolar lavage. ${ }^{18}$ Furthermore, Rathcke et al., in $2006^{7}$ reported that YKL-40 is produced at inflammation sites and is secreted from smooth muscle cells of blood vessels and macrophages, previous studies have demonstrated that the level of YKL-40 was increased during T-helper cell of type 2 inflammatory process. ${ }^{34}$

Tang et al., $(2013)^{13}$ revealed that YKL-40 may be involved in the inflammation of bronchial asthma by stimulating the secretion of IL-8 from epithelium which then contributes to Bronchial smooth muscle cells proliferation and migration. Collectively, YKL-40 has a role in inflammation, pathological fibrosis, and tissue remodeling. Bara et al., in $2012^{33}$ reported that YKL- 40 was found to stimulate proliferation of bronchial smooth muscle cells, its level in serum, and bronchial lavage fluid correlates with subepithelial membrane thickness. ${ }^{18}$ Some studies showing that circulating levels of YKL-40 was associated with a decline in lung function in the general population. ${ }^{39}$

Then again, Santos et al., in $2014^{37}$ determine whether YKL-40 levels correlate with increasing asthma severity in childhood asthma, they found that severe persistent asthma in childhood is not associated with elevated YKL-40 levels, unlike in adults with severe persistent asthma and concluded that YKL40 is not a useful biomarker for asthma severity in childhood asthma. Our results indicated that serum levels of YKL-40 were significantly positively correlated with the absolute eosinophilic count, similar results were found by Mohamed et al., in $2016^{21}$ who found that serum YKL40 showed a highly significant positive correlation with the eosinophilic count in the stable asthma group and in acute asthma. Also, comparable results were observed by Tang et al., in $2010^{13}$ and Lee et al., in $2012^{34}$ who reported that there were positive correlations between serum levels of YKL-40 and peripheral blood eosinophil count.

Regarding the results of the ROC curve, our results showed that the area under the curve was (0.869), the cut-off point was at $>25 \mathrm{ng} / \mathrm{ml}$. The sensitivity of the YKL-40 for diagnosis of asthma was $80.0 \%$ and the Specificity $83.3 .0 \%$ with high significant $\mathrm{p}$ value. The positive predictive value (PPV) was $82.7 \%$ and the negative predictive value (NPV) was $80.6 \%$, these results agreed with Mohamed et al., in $2016^{21}$ who found that a cut-off point of YKL-40 for 
diagnosis and screening of asthma was in $216.8(\mathrm{ng} / \mathrm{ml})$ and also, they found that YKL-40 had high sensitivity and specificity in diagnosis of childhood asthma and they concluded that YKL-40 could be a valuable biomarker for asthma diagnosis and prognosis. Also, Konradsen et al., in $2013^{24}$ reported that YKL-40 is a biomarker of severe asthma.

Abdel-Gawad et al., in $2011^{27}$ found that the YKL-40 best cut off value for asthma prognosis was $90 \mathrm{ng} / \mathrm{ml}$, with a sensitivity of $86.5 \%$, a specificity of $81 \%$, and the diagnostic accuracy of $85 \%$. They concluded that YKL-40 is considered a promising biomarker for asthma severity and pulmonary remodeling warranting further study as a potential novel pathway to disease management. Also, Ober and Chupp, in $2009^{29}$ reported a cut-off of 90 $\mathrm{ng} / \mathrm{ml}$ for YKL-40 was determined in asthmatic patients. Saba et al., in $2014^{37}$ found that the best YKL-40 cut-off point equal to 80.9 , in which the sensitivity and specificity were $79 \%$ and $84 \%$, respectively and $\mathrm{AUC}$ (area under curve) was equal to 0.88 . Also, they found that serum level of YKL-40 more than 122 $\mathrm{ng} / \mathrm{ml}$ with a maximum of $1 \%$ error in all patients with each severity. Also, they added that by increasing the serum level of YKL-40, sensitivity decreased, as there was a sensitivity of $89.5 \%$ at the cutoff point of YKL-40=92.7. They concluded that the serum level of YKL-40 can be a good diagnostic biomarker of asthma.

Also, Usemann et al., in $2016^{38}$ assessed YKL-40 levels at birth and its association with asthma, they reported that YKL-40 may be considered an early biomarker for asthma development. Also, Leonardi et al., in $2015^{30}$ reported that YKL-40 represents a useful biomarker of asthma in children with intermittent or persistent asthma. Also, Bargagli et al., in $2010^{19}$ reported that YKL-40 protein has been suggested to be a biomarker of severe asthma in adults. On the other hand, Santos et al., in $2014^{37}$ define whether YKL-40 serum levels correlate with increasing bronchial asthma severity in children. They stated that YKL40 is not a valuable biomarker for asthma severity in children.

\section{Conclusions and Recommendations:}

YKL-40 serum levels are significantly higher in asthmatic children compared to healthy controls. Serum levels of YKL-40 are significantly higher in acute asthmatics compared to stable asthmatics. YKL-40 serum levels correlate significantly with the severity of an acute asthma attack. YKL-40 might have a role in pediatric asthma pathogenesis.

Conduction of further research on the role of YKL-40 in pediatric asthma with a larger sample size with a longitudinal design. Construction of future studies on the prognostic assessment of serum level of YKL-40 levels in asthmatic children. Study of the role of YKL-40 in other pediatric pulmonary diseases characterized by inflammation e.g. pneumonia and cystic fibrosis. Study of YKL-40 as an objective biomarker to the degree of control of asthma.

\section{References:}

1. GINA. Global Initiative for Asthma: Global strategy for asthma management and prevention. Global initiative for Asthma web site. 2016; http://www.ginasthma.org/.

2. El-Hefney AM, Nassa SI, El-Heneidy FM. (1994): Epidemiology of childhood asthma in Cairo. Med J CairoUniver; 62:505-18.

3. El-Lawindi M, Mostafa N, Abu Hashim F,.( 2003). Bronchial asthma among children. Disease burden and exacerbations determinants. The Egyptian $\mathbf{J}$ of Community Medicine; 21: 59-76. 
4. Deraz TE, Aboulfotouh A, Habib NM et al. (2008). Study of prevalence of asthma and other atopic diseases among school children in Dakalia Governorate. Thesis Submitted for partial fulfillment of a Master Degree in Pediatrics.

5. Magdy Z, Ahmed S, Mohamed F. et al. ( 2009). Prevalence of bronchial asthma among Egyptian school children. Egyptian Journal of Bronchology; 3: (2) 124-8.

6. Johansen J.S., H.S. Jensen, P.A. Price (1993). A new biochemical marker for joint injury: analysis of YKL-40 in serum and synovial fluid Br J Rheumatol, 32, pp. 949955

7. Rathcke CN, Johansen JS, Vestergaard H.(2006). YKL-40, a biomarker of inflammation, is elevated in type 2 diabetes patients and is related to insulin resistance. Inflamm Res; 55: 53-9.

8. Volck B, Price PA, Johansen JS, Sørensen $\mathrm{O}$, Benfield $\mathrm{T}$, Calafat $\mathrm{J}$, Nielsen $\mathrm{H} \mathrm{J}$, Borregaard N.(1998) YK L-40, a mammalian member of the bacterial chitinase family, is a matrix protein of specific granules in human neutrophils. Proc Assoc Am Physicians; 110:351-60.

9. Kelleher T.B., S.H. Mehta, R. Bhaskar, M. Sulkowski, J. Astemborski, D.L. Thomas, et al (2005). Prediction of hepatic fibrosis in HIV/HCV co-infected patients using serum fibrosis markers: the SHASTA index $\mathrm{J}$ Hepatol, 43, pp. 78-84.

10.Kuepper M, Bratke K, Virchow JC(2008). Chitinase-like protein and asthma. N Engl J Med;358:1073-5.

11.Specjalski K, Jassem E (2011). YKL-40 protein is a marker of asthma. J Asthma.; 48(8):767-72

12.Duru S, Yu“ ce G, Ulasli S, Erdem M, Kizilgu“" n M, Kara F.( 2013) The relationship between serum YKL-40 levels and severity of asthma. Iran J Allergy Asthma Immunol;12:247-53.

13.Tang H, Fang Z, Sun Y, Li B, Shi Z, Chen J, et al. ( 2010) YKL-40 in asthmatic patients, and its correlations with exacerbation, eosinophils, and immunoglobulin E. Eur Respir J;35:757-60.
14.Nelson KA1, Zorc JJ (2013). Asthma update. Pediatr Clin North Am. Oct;60(5):1035-48.

15.Winer RA1, Qin $X$, Harrington $T$, Moorman J, Zahran H (2012). Asthma incidence among children and adults: findings from the Behavioral Risk Factor Surveillance system asthma call-back survey--United States, 2006-2008. J Asthma. Feb;49(1):16-22. 16.Eder W, Ege MJ, von Mutius E (2006). The asthma epidemic. N Engl J Med; 355:2226-35. 17. Snell N, Newbold P (2008). The clinical utility of biomarkers in asthma and COPD. Curr Opin Pharmacol; 8(3):222-35.

18.Chupp GL, Lee CG, Jarjour N, Shim YM, Holm CT, He S, Dziura JD, Reed J, Coyle AJ, Kiener P, et al. ( 2007). A chitinase-like protein in the lung and circulation of patients with severe asthma. N Engl J Med.;357:201627.

19.Bargagli E, Olivieri C, Margollicci M, Bennett D, Luddi A, Perrone M, et al. ( 2010) Serum chitotriosidase levels in patients with allergic and non-allergic asthma. Respiration;79:437-8.

20.Zhu Z, Zheng T, Homer RJ, Kim YK, Chen NY, Cohn L, et al. ( 2004). Acidic mammalian chitinase in asthmatic Th2 inflammation and IL-13 pathway activation. Science; 304(5677):1678-82.

21. Mohammed Iman A. a, Safia M. Diab b, Doaa R. Soliman a, Wael A. Shalaby a (2016). Study of serum YKL-40 in children with bronchial asthma. Egyptian Pediatric Association Gazette 64, 26-31

22.Awad HH (2007). Study of the prevalence of bronchial asthma and other atopic diseases among school children in Sharkia Governorate. Thesis submitted for partial fulfillment of a master degree in pediatrics. Faculty of Medicine, Ain Shams University under the supervision of Deraz, T.E.

23.Kikuchi I, Kikuchi S, Kobayashi T, Hagiwara K, Sakamoto Y, Kanazawa M, et al. ( 2006) Eosinophil trans-basement membrane migration induced by interleukin- 8 and neutrophils. Am J Respir Cell Mol Biol;34:760-5.

24.Konradsen J, James A, Nordlund B, Reinius LE, So“ derha“ 11 C, Mele'n E, et al. ( 
2013) The chitinase-like protein YKL-40: a possible biomarker of inflammation and airway remodeling in severe pediatric asthma. J Allergy Clin Immunol;132:328-35.

25.Bousquet J, Vignola AM (2006). Airways remodeling in asthma: no doubts, no more? Am J Respir Cell Mol Biol;20:777-86.

26.Jayaram L, Pizzichini MM, Cook RJ, Boulet LP, Lemiere C, Pizzichini E, et al. ( 2006) Determining asthma treatment by monitoring sputum cell counts: effect on exacerbations. Eur Respir J;27:483-94.

27.Abdel-Gawad Tarek, Mervat Gamal Eldin Mansour, Manal Abdel-Aziz, Bothina Elbialy (2011). Serum YKL-40 and assessment of severity of bronchial asthma in Egyptian children. Egypt J Pediatr Allergy Immunol;9(2):93-97.

28.Ober C, Tan Z, Sun Y (2008). Effect of variation in CHI3L1 on serum YKL-40 level, the risk of asthma, and lung function. $\mathrm{N}$ Engl $\mathbf{J}$ Med; 358:1682-91.

29. Ober C, Chupp GL (2009). The chitinase and chitinase-like proteins: a review of genetic and functional studies in asthma and immunemediated diseases. Curr Opin Allergy Clin Immunol; 9:401-8.

30.Leonardi S, Filippelli M1, Lanzafame A1, Parisi G1, Mistrello G2, Musubmeci M3, Torrisi V4, Musumeci S5, Cuppari C6 (2015). Serum ykl-40 in children with asthma. J Biol Regul Homeost Agents. 2015 Apr-Jun;29(2 Suppl 1):114-9.

31.Gavala ML, Kelly EAB, Esnault S, Kukreja S, Evans MD, Bertics PJ, et al. (2013) Segmental allergen challenge enhances chitinase activity and levels of CCL18 in mild atopic asthma (pages 187-197). Clin Exp Allergy;43:187-97.
32.Bigg HF, Wait R, Rowan AD, Cawston TE (2006). The mammalian chitinase-like lectin, YKL-40, binds specifically to type I collagen and modulates the rate of type I collagen fibril formation. J Biol Chem;281:21082-95.

33.Bara I, Ozier A, Girodet PO, Carvalho G, Cattiaux J, Begueret H, et al. (2012) Role of YKL-40 in bronchial smooth muscle remodeling in asthma. Am J Respir Crit Care Med;185:715-22.

34.Lee CG, Da Silva CA, Dela Cruz CS, Ahangari F, Ma B, Kang MJ, et al. ( 2011) Role of chitin and chitinase/chitinase-like proteins in inflammation, tissue remodeling, and injury. Annu Rev Physiol;73:479-501.

35.Moffatt MF, Cookson WO (2008). Asthma and chitinases. N Engl J Med; 358(16):1725-6.

36. Santos CB1, Davidson J1, Covar RA1, Spahn JD2 (2014). The chitinase-like protein YKL-40 is not a useful biomarker for severe persistent asthma in children. Ann Allergy Asthma Immunol. 2014 Sep;113(3):263-6.

37.Saba M, Sharif MR, Akbari H, Nikoueinejad H, Ramazani Jolfaii M (2014). YKL-40 in Asthma and its correlation with different clinical parameters. Iran J Allergy Asthma Immunol;13(4):271-7.

38.Usemann Jakob, Urs Frey, Ines Mack, Anne Schmidt, Olga Gorlanova1, Martin Röösli3,4, Dominik Hartl5 and Philipp Latzin (2016). CHI3L1 polymorphisms, cord blood YKL-40 levels and later asthma development. BMC Pulmonary Medicine 16:81

39. Sakazaki Y, Hoshino T, Takei $\mathrm{S}$ et al (2011) Overexpression of chitinase 3-like $1 /$ YKL-40 in lung-specific IL-18-transgenic mice, smokers and COPD. PLoS One 6:e24177. 